\title{
Using a Mobile Phone to Support Learning: Experiences of Engineering Students in Libya
}

\author{
Amal Rhema and Ewa M. Sztendur \\ Victoria University, Melbourne, Victoria
}

\author{
Amal.Rhema@live.vu.edu.au; Ewa.Sztendur@vu.edu.au
}

\begin{abstract}
Mobile phones have been identified as the catalyst for offering portable, real-time communication and access to information. In developing countries, where the adoption of mobile phones has reached remarkable levels, mobile phones are seen as a key means for improving access to education. In Libya, mobile phones offer a much more reliable and affordable way to reach students than technologies that have high physical infrastructure requirements. This article presents findings from a case study carried out at two Libyan Universities and concerns engineering students' experience and perceptions of using mobile phones to support their learning. The findings focus primarily on how students use their mobile phones to support learning. The article also provides an analysis of relationships between students' demographic characteristics and access to technology, and use of mobile phones for learning.
\end{abstract}

Keywords: Mobile phone, smartphone, m-learning, e-learning, portable devices, developing country, digital divide, ICT, information and communication, engineering students.

\section{Introduction}

As university students have become increasingly busy and physically mobile, their use of a variety of technologies has also increased. Smartphones, tablets, laptops, and other portable devices have been indispensable for the majority of young people in developed countries. In 2008, the Horizon Report speculated that the increased need for delivery of services and content to mobile and personal devices would be one of the greatest challenges that higher education would face (Johnson, Levine, \& Smith, 2008). The future envisioned in the Horizon Report was echoed in Kim, Lee, Merrill, Spector, \& van Merriënboer (2008) who predicted that mobile technologies will have an important place in learning and teaching, giving new opportunities to move learning out of the classroom. It appears that in 2012 this trend has been present already. Consistent with recent reports, mobile applications have been 'the fastest growing dimension of the mobile space in higher education right now, with impacts on virtually every aspect of informal learning, and increasingly, every discipline in the university' (Johnson, Adams, \& Cummins, 2012, p. 6). Mo-

Material published as part of this publication, either on-line or in print, is copyrighted by the Informing Science Institute. Permission to make digital or paper copy of part or all of these works for personal or classroom use is granted without fee provided that the copies are not made or distributed for profit or commercial advantage AND that copies 1) bear this notice in full and 2) give the full citation on the first page. It is permissible to abstract these works so long as credit is given. To copy in all other cases or to republish or to post on a server or to redistribute to lists requires specific permission and payment of a fee. Contact Publisher@InformingScience.org to request redistribution permission. bile devices with numerous applications and always connected to the Internet have the capacity to create collaborative learning environments and permit efficient communication regardless of time or location. Constant connectivity via mobile broadband networks allows access to tools for searching and browsing, publishing, communication via email, video and audio conferencing, and access to social networking (Andrews, 
Smyth, Tynan, Berriman, Vale, \& Caladine, 2011; Johnson et al., 2012). The rapid expansion of mobile technology has also been heralded as a key means for providing access to those who are currently missing out on education. According to Puumalainen, Frank, Sundqvist, \& Tappura (2011):

Mobile technology may have its greatest impact in the developing world, because it brings telephony to districts [that] fixed-line telephones formerly never reached. However, as data has not been available until recently, empirical evidence on mobile telephony impact or diffusion in developing countries is scarce (Puumalainen et al.. 2011, p. 2).

It is not surprising that many education researchers around the world have been quick to explore the potential of these technologies to provide access, as well as improvements for the learning environment. Research into deployment of mobile technologies for learning in developing countries has also grown, but remains limited (Kok, 2011).

This article aims to complement the existing knowledge by providing findings from a case study carried out at two Libyan Universities. The findings focus primarily on the experience of engineering students with mobile technologies, particularly, access to technology outside the university, ways in which students use a mobile phone - whether for learning or other purposes - and perceived usefulness of mobile phone functions in learning. In addition, the article provides an analysis of relationships between students' demographic characteristics and access to technology, and use of mobile phones for learning.

\section{Literature Review}

\section{The Role of Mobile Telecommunication in Arab Countries}

Unreliable infrastructure for fixed phone lines as well as 'liberal regulatory environments and global market penetration' have allowed for speedy growth of mobile telecommunications in developing regions (Uys, Brann, Klapdor \& Smith, 2012, p. 579). The rapid acquisition of mobile technologies among the poorest nations enables people to create significant opportunities for economic growth, health care enhancement and increased access to education for people living in these countries (Andrews et al., 2011). Zuckerman (2009) has reported that from $80 \%$ to $90 \%$ of the public in some poor countries have at least minimal access to a mobile phone. Furthermore, nearly 80 million mobile subscribers, most of them in developing countries, have no access to the electrical grid and yet use a mobile phone.

In the Middle East region (excluding the North African countries) mobile penetration rates were anticipated to reach 93.9\% in 2011 and $125.5 \%$ in 2015. Iran and Afghanistan have reported significant subscription growth in the region. In 2010, Iran ranked the single biggest mobile market, with 66 million subscriptions, followed by Saudi Arabia, with 42.9 million subscriptions. Yet, Saudi Arabia was the most valuable mobile market in the Middle East region in 2010 with revenues of more than $\$ 11$ billion. It is expected that mobile subscriptions in the Middle East region will reach 327 million in 2015 (Cherrayil, 2010). In the Gulf region, countries such as United Arab Emirates and Qatar, the mobile phone penetration rate is more than $100 \%$. Even in poorer countries affected by war, like Palestine and Yemen, an increase in mobile phone penetration is expected in the next few years because of a growing youth market and emergence of new telecommunication operators (Muttoo, 2011; UNESCO, 2012). Cherrayil (2010) reported that the Palestinian market recorded the fastest growth in 2010, with mobile subscriptions increasing by $56 \%$.

The Arab region represents one of the fastest growing mobile phone markets in the world with mobile phone penetration being much faster than the Internet penetration (Muttoo, 2011). Ac- 
cording to a study conducted by Gallup (2011), 87\% of young Arabs aged between 15 and 29 reported having access to mobile phones in 2010, an increase from $79 \%$ in 2009. Arab countries have utilized mobile phones to empower communities through various innovative mobile phone applications. For example, in Jordan, the Bedouin women, who are not culturally allowed to seek help without their husband's permission, consult doctors via mobile phones. Mobile phones have given these women the opportunity to ask for medical advice which has the potential to generate long-term positive impact on their health. A further example, in Syria an 'Electronic Voucher System' was commenced in 2009 to alleviate food insecurity among Iraqi refugee families in Damascus. Through this programme, which is the first of its kind in the world, Iraqi refugees receive vouchers on their mobile phones to purchase food items from government-owned stores (Muttoo, 2011). The local telecom operator provides SIM cards to refugee families free of charge. In addition, mobile phones have the potential to organize political action and boost the functional capacity of organizations and individuals during demonstrations, for example in the recent uprising. They are an important mechanism for bringing people out into the streets. Having assumed a significant role in the political settings of Arab countries, mobile phones will continue to mobilize people during elections and future social movements (Muttoo, 2011).

In Libya, over the last decade, mobile phone penetration in Libya has increased dramatically, from $1 \%$ in 2001 to $171 \%$ in 2010, indicating multiple subscriptions per person (International Telecommunication Union [ITU], 2012). Libya's government leveraged mobile-broadband technology in order to compensate for the lack of fixed infrastructure. In 2010, there were nearly 10.9 million mobile-cellular subscriptions and 2.7 million active mobile-broadband subscriptions in the country (ITU, 2012).

The 2011 armed conflict in Libya completely transformed every aspect of daily life, including communication and Libya Telecom and Technology (LTT) services. It halted progress in the country and set back the gains built up over generations, disrupted economic growth and advances in nutrition, health, housing, education and employment (Rhema, \& Miliszewska, 2012). The Libyan League for Human Rights has reported that the amount of material losses reached \$575 billion (Aljazeera.net, 2011). Even before the recent armed conflict and a relatively high income level, Libya's ICT networks, projects and adoption have remained poor in relation to its counterparts (in terms of national income). This is mainly because of a political environment in which the ICT market has been controlled by a state-owned monopoly, except for mobile-cellular (voice) services, where two state-owned operators are competing with each other. In October 2011, LTT started its reconstruction and maintenance work and carried out technical operations to reinstate their services in the affected areas such as Misurata and Bani Waleed. LTT has set February 2012 as the deadline to return the service to its state prior to the Libyan revolution (ITU, 2012).

Information and communications technologies (ICTs) and mobile phones have played a vital role in facilitating the communication and organization the Libyan revolution which took place on $17^{\text {th }}$ of February 2011 (Libyan Ministry of Communication and Informatics, 2012; Jones et al., 2012). According to Jones and colleagues (2012), extensive cellular coverage and high rates of cell phone use in Libya suggest that mobile devices have a promising role to play in election monitoring. With donor support, the Shahed Network for Election Monitoring (SNEM) could implement a reporting system based on mobile technology, allowing observers to submit data directly via SMS (Jones et al., 2012).

\section{Mobile Learning}

It has been suggested in the literature that mobile phones have great potential to relieve educational disadvantage by providing opportunities for increased access to education for the poor and those who have limited access to education. As Kok (2011) points out: 
Because mobile phones are increasingly becoming part of the everyday lives of the poor, it is argued that they have potential to become a low cost accessible delivery channel for learning services, thus facilitating innovations including m-learning (2011, p. 69).

Mobile (m-) learning has been perceived as a promising approach to complement student learning by providing more study opportunities to learners anytime anywhere. Placed within the e-learning framework, mobile learning has emerged as a tool which allows students to access learning materials, perform learning tasks, participate in learning interactions, undertake assessment tasks, learn work processes, access learning support, and evaluate teaching (Uys et al., 2012 ). The promise of mobile learning has also been the ability to provide opportunities for learning embedded in a natural environment, allowing learners to engage in learning-related activities in diverse physical locations, supporting group work on projects, and enhancing communication and collaborative learning in the classroom (Liu, Wang, Liang, Chan, Ko, \& Yang, 2003; Suki \& Suki, 2007).

Mobile learning has acquired a variety of different meanings. Traxler (2007) as well as Uys and colleagues proposed that "mobile learning deals with the mobility of the learner, so that learning can occur anywhere/anytime" (Uys et al., 2012, p. 575). Mobile learning supports and promotes personalized learning as mobile devices are focused on the learner rather than the institution. Learners use some type of mobile handheld computer, such as a PDA, smart phone, tablet PC, games console or other portable device and make use of the device's connectivity as well as its tools and content to learn regardless of where they are and what time it is.

Some authors heralded mobile learning as the next progressive step from e-learning and others simply view it as an advanced tool that integrates with e-learning (Caudill, 2007); they see mobile learning as the direct descendant of e-learning. Hoppe, Joiner, Milrad \& Sharples (2003) and Chang, Sheu \& Chan (2003) defined mobile learning as "e-learning using mobile devices and wireless transmission" (Iqbal \& Qureshi, 2012, p.147). While e-learning is mostly dependent upon desktop personal computing technology, mobile learning is dependent upon mobile devices (Orr, 2010; Iqbal \& Qureshi, 2012). E-learning using laptops or desktop computers connected to the Internet offers solid, multimedia rich, web-based solutions, however, desktop based elearning lacks the portable and ubiquitous nature of mobile learning (Nash, 2011).

Owing to their highly portable and wireless nature, mobile phones and mobile learning have been seen as a means of extending learning opportunities to remote areas, thus supporting the expansion of educational access. According to Nash (2011, p. 93), "in some countries, m-learning is more of a necessity than a luxury" due to limited connectivity to the high-speed Internet at homes and profusion of mobile phones. However, Kok (2011), in her review of the current state of knowledge about mobile learning in developing countries, pointed to the absence of a strong evidence base and warned about the tendency to exaggerate the potential of mobile learning applications for poor users. On the other hand, according to UNESCO (2012), the continuous advances in technology and the rapid and widespread uptake of mobile phones across developing countries have led to positive educational transformation over the last few years.

In China, an important pilot study of m-learning, the Mobile Campus Program, was conducted at the Shanghai TV University. The Program enabled students in 41 remote branches to use smart phones to access the SMS System, allowing a quick delivery of educational and administrative information (Sun, 2008; Yang \& Wang, 2011). The study findings revealed that most of the study participants believed that Mobile Campus contributed to their learning, helped them to understand lecture's key points and increased their access to college services. However, the project identified some issues, such as low learning efficacy, limits of mobile devices, limited m-learning resources, and little guidance given in the learning process (Sun \& Chen, 2007; Yang \& Wang, 2011). 
The issues of self-efficacy as well as the importance of guidance and timely feedback have also been discussed by Nash (2011). The author presented an overview of mobile learning strategies used in developing countries for learners in remote locations with limited Internet connectivity. Mobile devices were used to provide interactivity and share instructional content for diverse cohorts of students in different learning environments in Paraguay, Iraq, Afghanistan and Colombia. The author identified several factors that need to be considered when planning mobile instructional strategies, chief among them an examination of learning objectives and realistic evaluation of students' preferences and their learning conditions, such as access to software and hardware.

In Arab countries, mobile learning is still in its inception phase. Yet, some universities have already adopted the Short Message Service (SMS) for teaching and learning in Saudi Arabia. For example, King Saud University has recently initiated a new service that offers users the ability to send text messages directly from a personal computer to a mobile phone (Altameem, 2011).

In Libya, where e-education is considered one of the most important success factors in building the new Libya, mobile-broadband technology could offer much more accessible and affordable alternative to the Internet based and unreliable land-line infrastructure (Rhema, \& Miliszewska, 2012). Using mobile phones as a platform for e-learning where content is delivered via text messages can be particularly useful at a time when the necessary infrastructure for the Internet connection does not exist. Mobile phones can enable increased access to education, broaden knowledge networks for students, improve availability of quality education materials, facilitate informal learning, and minimize the digital divide.

\section{Digital Divide in Developing Countries}

Generally, the concept of digital divide refers to the gap or inequity that exists between those who have access to ICT and also to the unequal access of resources. The digital divide can exist between those living in rural areas and those living in urban areas, between the educated and uneducated, between economic classes, and also on a global scale between developed and developing nations (CARICOMICT4D, 2012). According to United Nation (2005), 'the term digital divide refers to the differences in resources and capabilities to access and effectively utilize ICT for development that exist within and between countries, regions, sectors and socio-economic groups; it is often characterized by low levels of access to technologies' (United Nation, 2005, p.2). Gorski (2001) stated that digital divide refers to inequalities in access to ICTs between groups of people based on one or more social or cultural identifiers. Under this conceptualization, researchers tend to compare rates of access to technology among individuals based on gender. Similarly, the digital gender divide refers to the gap in usage rates between men and women.

In Sub-Saharan African countries, the divide between urban and rural areas is even greater than in the rest of the world (UN ICT Task Force, 2002). Gallup surveys (2011) show that the urban SubSaharan Africans are more likely to be mobile phone users: in the 17 countries surveyed, $69 \%$ of Sub-Saharan Africans living in urban areas and 53\% from rural areas have a mobile phone. On the other hand, the results showed that Africans living in rural areas in Ghana and South Africa were more likely to be mobile phone owners (urban 58\%, rural $60 \%$ in Ghana) and (urban $82 \%$, rural $86 \%$ in South Africa (Tortora \& Rheault, 2011). Most of the services and users are concentrated in the cities, while the majority of Africans are scattered in small communities spread out across huge rural areas. The limited spread of the telecommunication networks into rural areas and irregular or non-existent electricity supplies are a common feature of these countries and a major barrier to the use of ICT, especially outside the major cities (Bjørn \& Stein, 2007). Further factors contributing to the divide are low income levels in rural communities, as well as low computer literacy and inability to contextualize the benefits of ICT in improving the quality of life (Nair, Han, Lee, Goon \& Muda, 2010; Tortora \& Rheault, 2011). 
The digital gender divide is evident in both traditional and modern technologies (Gill et al., 2010), and the significance of the gender divide varies across developed and developing nations and over time (Liff \& Shepherd, 2004), however, it is larger in developing countries (Gillwald et al., 2010; Gill et al., 2010). In most developing countries, men outnumber women in using the Internet, mobile phones, and radios. Women are approximated to be $25 \%$ or less of Internet users in Africa, 20 to 22\% in Asia, 38\% in Latin America, and 6\% in the Middle East (Gill et al., 2010). Gallup surveys (2011) show that, in the 17 Sub-Saharan countries, males (62\%) are more likely than females (52\%) to have access to mobile phones (Tortora \& Rheault, 2011).

In Africa and Middle East, there are considerable gender inequalities in access to mobile subscriptions. A research study by Research ICT Africa (RIA) found that there are substantially more male mobile customers than female in Zambia, Senegal, Benin and Uganda. This trend may be attributed to a combination of unequal distributions of income and higher illiteracy rates among women. The inverse holds true in South Africa, Cameroon and Mozambique, where female mobile subscribers tend to dominate male customers (Gillwald et al., 2010; UNESCO, 2012).

\section{Purpose of the Study}

The findings presented in this article come from a major study investigating the e-learning experiences of engineering students at two Libyan universities. The results described here focus on students' experiences with mobile phone technologies. The following research questions guided the research presented in this article:

(1) What levels of access to commonly available technologies do students have outside the university?

(2) Are there significant differences in the level of access between female and male students?

(3) Are there significant differences in the level of access between students from an urban university and students from a rural university?

(4) What is the level of use of mobile phones to support learning?

(5) Are there significant differences in the level of use of mobile phone to support learning between female and male students?

(6) Are there significant differences in level of use of mobile phone to support learning between students from an urban university and students from a rural university?

(7) What are the perceptions of students regarding the usefulness of a mobile phone to support learning?

\section{Methodology}

\section{Survey Instrument}

An instrument developed by Kennedy et al. (2006) was adopted and modified to accommodate the needs of this study. The survey section "Access to Technology" consisted of 10 items (technologies) and students were asked to indicate their level of access outside the University. The options provided were: "No access", "Limited or inconvenient access", and "No problem with access".

Students were also asked to indicate how they used mobile phone tools. They could choose between: "Don't know this technology", "To support learning", and "For other purposes". Students were allowed to select both "To support learning" and "For other purposes" if the two options applied to them.

Participants were also provided with a list of mobile-based tools that might be useful in their learning environment. They were asked to apply a rating scale (from " 1 " 'strongly disagree' to 
" 5 " 'strongly agree') to indicate their agreement with how useful each of these technologies would be in supporting their learning or teaching. If the participants were not sure about a particular technology, they were asked to select the "don't know" option. The categories in the rating scales have been collapsed to facilitate statistical analysis and ease of interpretation. Categories "strongly disagree" and "disagree" were merged into a single category, "generally disagree"; categories "agree" and "strongly agree" were combined into a single category, "generally agree" (See Appendix C).

A paper-based questionnaire was administered in 2011 to engineering students at two Libyan universities, the University of Tripoli and the regional Al-Jabal Al-Gharbi University. The following section provides information about participants and participating institutions.

\section{Participants}

Table 1 provides general information about the participating Universities, their Engineering Faculties and the Schools participating in this study. The University of Tripoli, established in 1957, is located in the capital city, Tripoli. It is one of the oldest and largest universities in Libya. On the other hand, the Al-Jabal Al-Gharbi University, established in 1985, is located almost 100KM southwest of Tripoli and is one of the biggest regional universities in Libya. Both institutions are funded by the Government. Throughout 2011, the escalation of the armed conflict in Libya has impeded the provision of educational services at both Universities. The significant impact of the conflict on these institutions has resulted in: attrition of students and instructors, leading to extended closure of campuses (more than nine months); destruction of educational infrastructure, including libraries and laboratories; and, power outages.

Table 1 : Characteristics of participating institutions.

\begin{tabular}{|c|c|c|c|c|}
\hline & \multicolumn{2}{|c|}{ University of Tripoli } & \multicolumn{2}{|c|}{ Al-Jabal Al-Gharbi University } \\
\hline Location & \multicolumn{2}{|c|}{ Urban } & \multicolumn{2}{|c|}{ Regional } \\
\hline Established & \multicolumn{2}{|c|}{1957} & \multicolumn{2}{|c|}{1985} \\
\hline Student population & \multicolumn{2}{|c|}{115,000} & \multicolumn{2}{|c|}{20,000} \\
\hline \multirow[t]{2}{*}{ Instructor populations } & \multicolumn{2}{|c|}{1,800} & \multicolumn{2}{|c|}{1,000} \\
\hline & \multicolumn{2}{|c|}{ Faculty of Engineering } & \multicolumn{2}{|c|}{ Faculty of Engineering } \\
\hline Established & \multicolumn{2}{|c|}{1961} & \multicolumn{2}{|c|}{1991} \\
\hline Student population & \multicolumn{2}{|c|}{8,500} & \multicolumn{2}{|c|}{1,300} \\
\hline \multirow[t]{3}{*}{ Instructor populations } & \multicolumn{2}{|c|}{300} & \multicolumn{2}{|c|}{100} \\
\hline & Group A & Group B & Group C & Group D \\
\hline & Elec. Eng. & Petr. Eng. & Elec.Eng. & Petr.Eng. \\
\hline Established & 1961 & 1970 & 1991 & 2004 \\
\hline Student population & 1,200 & 700 & 150 & 160 \\
\hline Instructor populations & 80 & 12 & 20 & 13 \\
\hline
\end{tabular}

Table 2 gives the demographic characteristics of the participants. Students in Group A represented more than half of all participants from the University of Tripoli. Almost two thirds of Group A students were female and less than half of Group B students were female. In both groups there were more mature students (aged 23 and over) than younger students. Also, the greatest number of respondents in both groups were in either their third or fourth year of study. Only 7\% of Group A and $11 \%$ of Group B students were in the first year of study. 
Table 2: Demographic characteristics of participants.

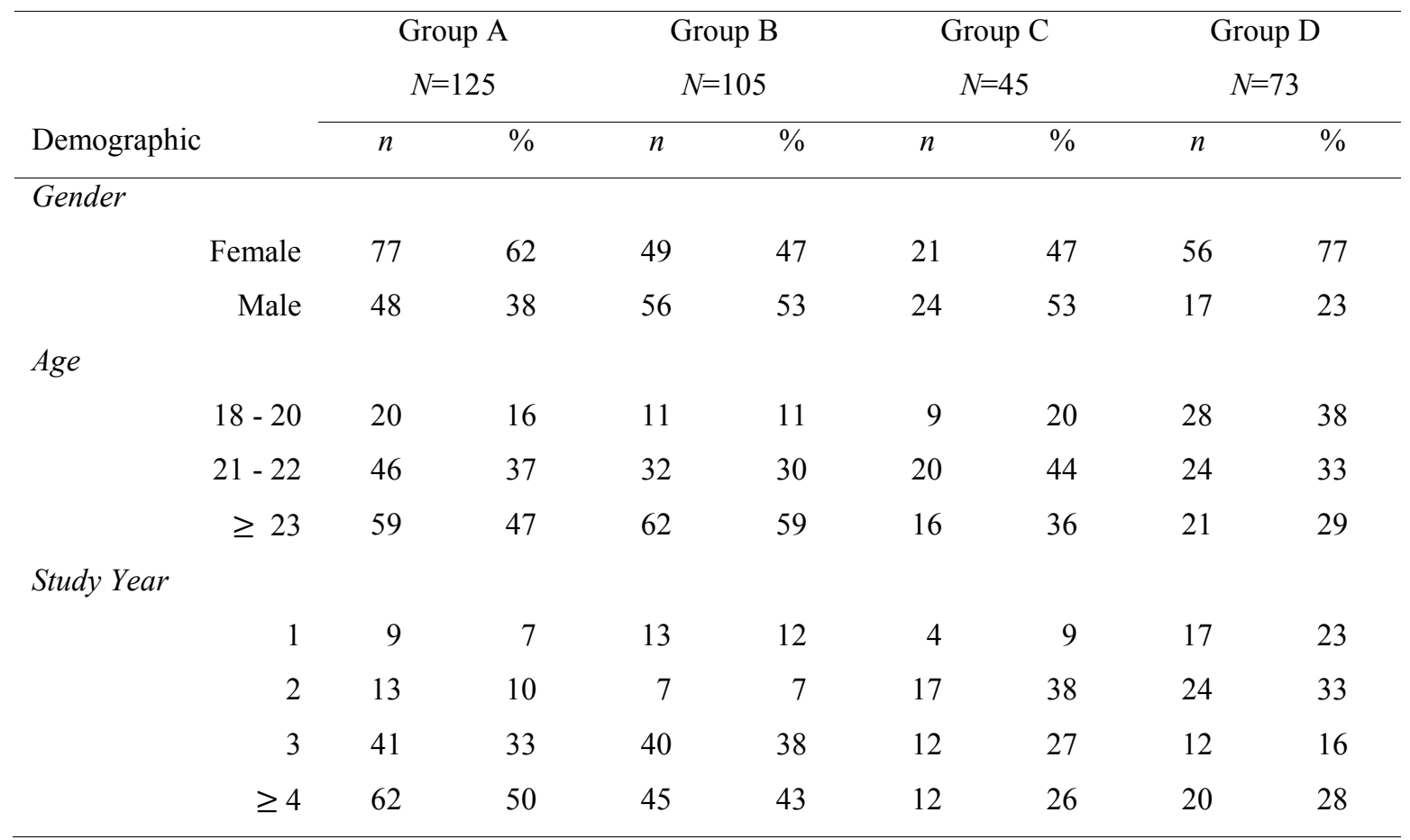

Students in Group D represented almost two thirds of all participants from the Al-Jabal Al-Gharbi University. More than half of Group C students were male and more than three quarters of Group $\mathrm{D}$ students were female. The proportion of younger respondents in these two groups was higher than in Group A and Group B. The greatest number of respondents in both Group C and Group D were in their second year of study. As was the case with Group A and Group B, the proportion of participants in their first and third year of study was considerably lower in Group C and Group D: $9 \%$ and $23 \%$ respectively in their first year. These lower rates for first year could be attributed to lower enrolment numbers in 2011 and 2012, caused by the outbreak of the armed conflict in Libya in February 2011 and the subsequent reconstruction of the country in 2012.

\section{Data Analysis}

Statistical models, using SPSS v. 19, were developed to relate the response variables to a number of student demographics. Ordinal logistic regression (Venables and Ripley, 2002) was used to determine what demographic characteristics of students were associated with levels of access to technology. (See Appendix A for mathematical description of the models used). There were five response variables that reflected student access to technology: (1) access to desktop computer, (2) access to laptop computer, (3) access to mobile phone, (4) access to video $3 \mathrm{G}$, and (5) access to high-speed Internet. The levels of response variables were: 0 - no access, 1 - limited access, and 2 - unrestricted access.

In addition, logistic regression was used to determine how demographic characteristics affect levels of use of mobile phones for learning. Students were asked how they used their mobile phone. The mobile phone tools provided were: (1) using a mobile phone to text /MSM people, (2) using a mobile phone to access information or services on the web, and (3) using a mobile phone to send or receive emails. They could answer: "Don't know this technology", "To support learning", and "For other purposes". Students were allowed to select both "To support learning" and "For other purposes" if the two options applied to them. For the purpose of statistical modelling, the 
three response variables were then reduced to a dichotomous form ( 0 - not used to support learning, and 1 - used to support learning).

While the factors of primary interests were Gender and Group, other demographic characteristics were also used as confounding variables. Hence, the explanatory variables were Gender ( 0 - $f e-$ male, 1 - male), and three sets of dummy variables to reflect study group: Group B, Group $C$, Group D, age: Age 21-22, Age $\geq 23$, and study year: Year 2, Year 3, Year $\geq 4$ ).

\section{Findings}

\section{Student Access to Technology}

The results related to students' access to various technologies and high-speed Internet for all participating groups are reported in Table 3. A high proportion of students in Group A and Group B had unrestricted access to a desktop computer: $80 \%$ and $82 \%$ respectively. Moreover, $56 \%$ of Group A students and $64 \%$ of Group B students reported having unrestricted access to a portable computer. Students in the regional University reported slightly lower access to a desktop computer; 69\% in Group C and 80\% in Group D had unrestricted access; 58\% of Group C students and $56 \%$ of Group D students reported having unrestricted access to a portable computer. In addition, $4 \%$ of Group $\mathrm{C}$ respondents and $13 \%$ of Group D respondents reported having no access to a desktop computer; and, a further 11\% of Group C respondents and 19\% of Group D respondents had no access to a laptop computer.

Table 3: Student access to technologies (represented as observed percentages).

\begin{tabular}{|c|c|c|c|c|c|c|c|c|c|c|c|c|}
\hline & \multicolumn{3}{|c|}{ Group A } & \multicolumn{3}{|c|}{ Group B } & \multicolumn{3}{|c|}{ Group C } & \multicolumn{3}{|c|}{ Group D } \\
\hline & $N A$ & $L A$ & $U A$ & $N A$ & $L A$ & $U A$ & $N A$ & $L A$ & $U A$ & $N A$ & $L A$ & $U A$ \\
\hline $\begin{array}{l}\text { Desktop } \\
\text { computer }\end{array}$ & 2 & 18 & 80 & 1 & 17 & 82 & 4 & 27 & 69 & 13 & 7 & 80 \\
\hline $\begin{array}{l}\text { Portable } \\
\text { computer }\end{array}$ & 14 & 30 & 56 & 7 & 30 & 64 & 11 & 31 & 58 & 19 & 25 & 56 \\
\hline $\begin{array}{l}\text { Memory } \\
\text { stick }\end{array}$ & 9 & 24 & 67 & 5 & 23 & 72 & 18 & 22 & 60 & 8 & 14 & 78 \\
\hline $\begin{array}{l}\text { Digital } \\
\text { camera }\end{array}$ & 26 & 35 & 39 & 15 & 38 & 47 & 9 & 53 & 38 & 25 & 22 & 53 \\
\hline $\begin{array}{l}\text { Web } \\
\text { camera }\end{array}$ & 43 & 22 & 35 & 24 & 40 & 36 & 38 & 38 & 24 & 31 & 35 & 35 \\
\hline Mobile phone & 1 & 5 & 94 & 0 & 6 & 94 & 4 & 22 & 74 & 4 & 8 & 88 \\
\hline Video $3 \mathrm{G}$ & 22 & 30 & 47 & 17 & 28 & 55 & 27 & 24 & 49 & 10 & 23 & 67 \\
\hline $\begin{array}{l}\text { Dial-up In- } \\
\text { ternet }\end{array}$ & 21 & 29 & 50 & 19 & 37 & 44 & 16 & 47 & 38 & 21 & 40 & 39 \\
\hline $\begin{array}{l}\text { High-speed } \\
\text { Internet }\end{array}$ & 9 & 13 & 78 & 6 & 19 & 75 & 11 & 29 & 60 & 7 & 25 & 68 \\
\hline
\end{tabular}

NA: no access, LA: limited access, UA: unrestricted access. (Note: Access to high-speed Internet represents access to either broadband or wireless Internet) 
The results of ordinal regression models presented in Table 4 show that there were significant differences in the reported level of access between females and males for a number of technologies.

- Female students were less likely than their male counterparts to have unrestricted access to a desktop computer. They were also more likely to report 'no access' or 'limited access' to a desktop computer (see also Figure A1 (a) in Appendix B)

- Female students were also more likely to report 'no access' to a laptop computer (Figure A1 (b) in Appendix B);

- Female students were less likely than male students to have unrestricted access to a memory stick. They were also more likely to report 'no access' or 'limited access' to a memory stick (Figure A1 (c) in Appendix B);

- Female students were less likely than male students to have unrestricted access to a web camera. They were also more likely to report 'no access' to a web camera (Figure A1 (d) in Appendix B);

- Female students were less likely than male students to have unrestricted access to dial-up Internet. They were also more likely to report 'no access' or 'limited access' to a dial-up Internet (Figure A1 (e) in Appendix B);

- Female students were less likely to have unrestricted access to the high-speed Internet. They were also more likely to report 'no access' or 'limited access' to the high-speed Internet (Figure A1 (f) in Appendix B).

The results in Table 4 also show that there were significant differences in the reported level of access between the groups from the urban university and the rural university.

- Students in Group C were less likely than students in other groups to have unrestricted access to a memory stick. They were also more likely to report 'no access' or 'limited access' to a memory stick (Figure A2 (a) in Appendix B);

- Students in Group C and Group D were less likely than students in Group A and Group B to have unrestricted access to a mobile phone, with students in Group $\mathrm{C}$ being the least likely to have unrestricted access to a mobile phone and most likely to report 'limited access' to a mobile phone (Figure A2 (b) in Appendix B);

- Students in Group D were most likely to report unrestricted access to Video 3G technology (Figure A2 (c) in Appendix B);

- Students in Group C were less likely to report 'unrestricted access' to the high-speed Internet. They were also more likely to report 'no access' or 'limited access' to the highspeed Internet than students in other groups (Figure A2 (d) in Appendix B). 


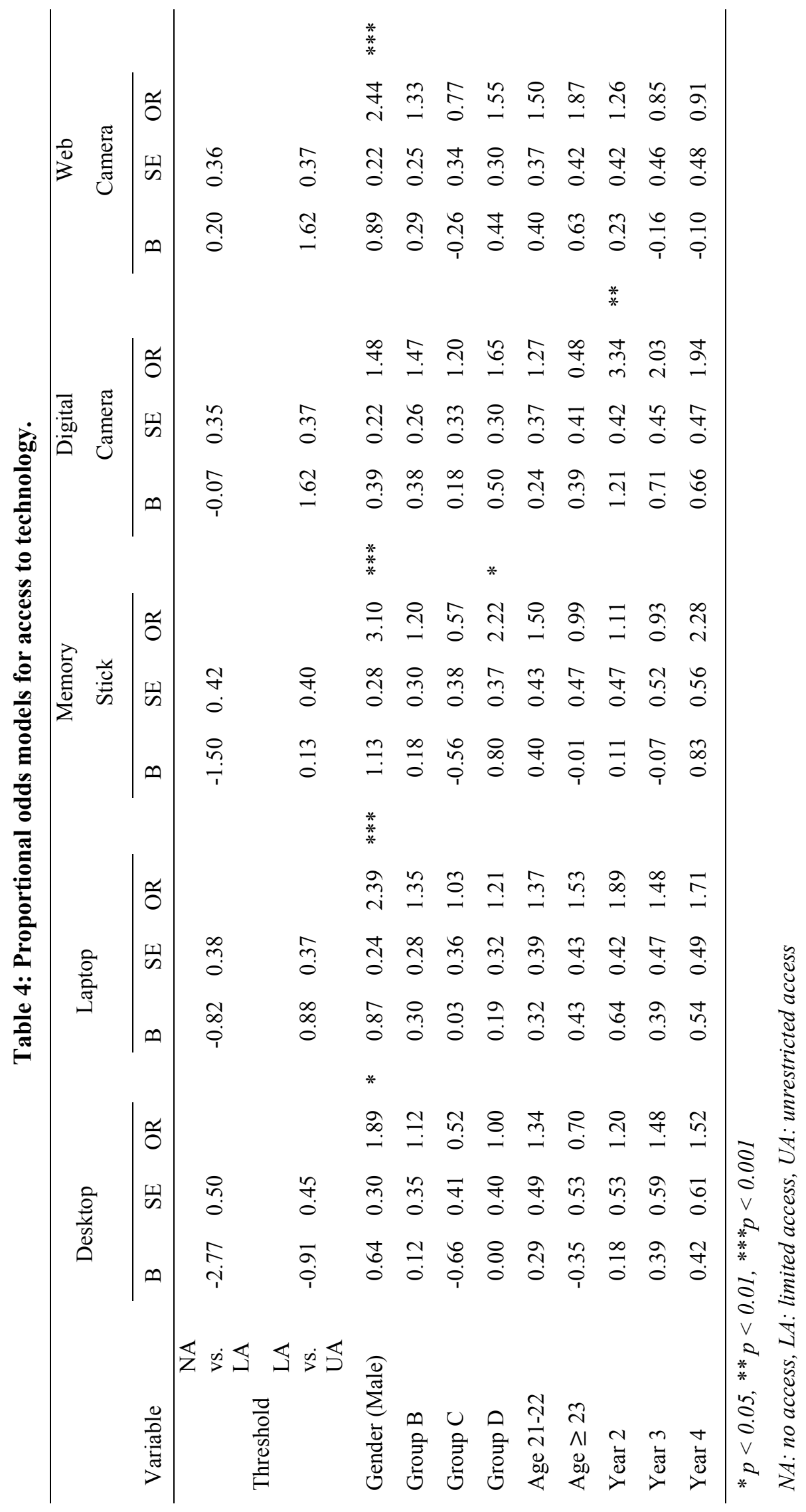




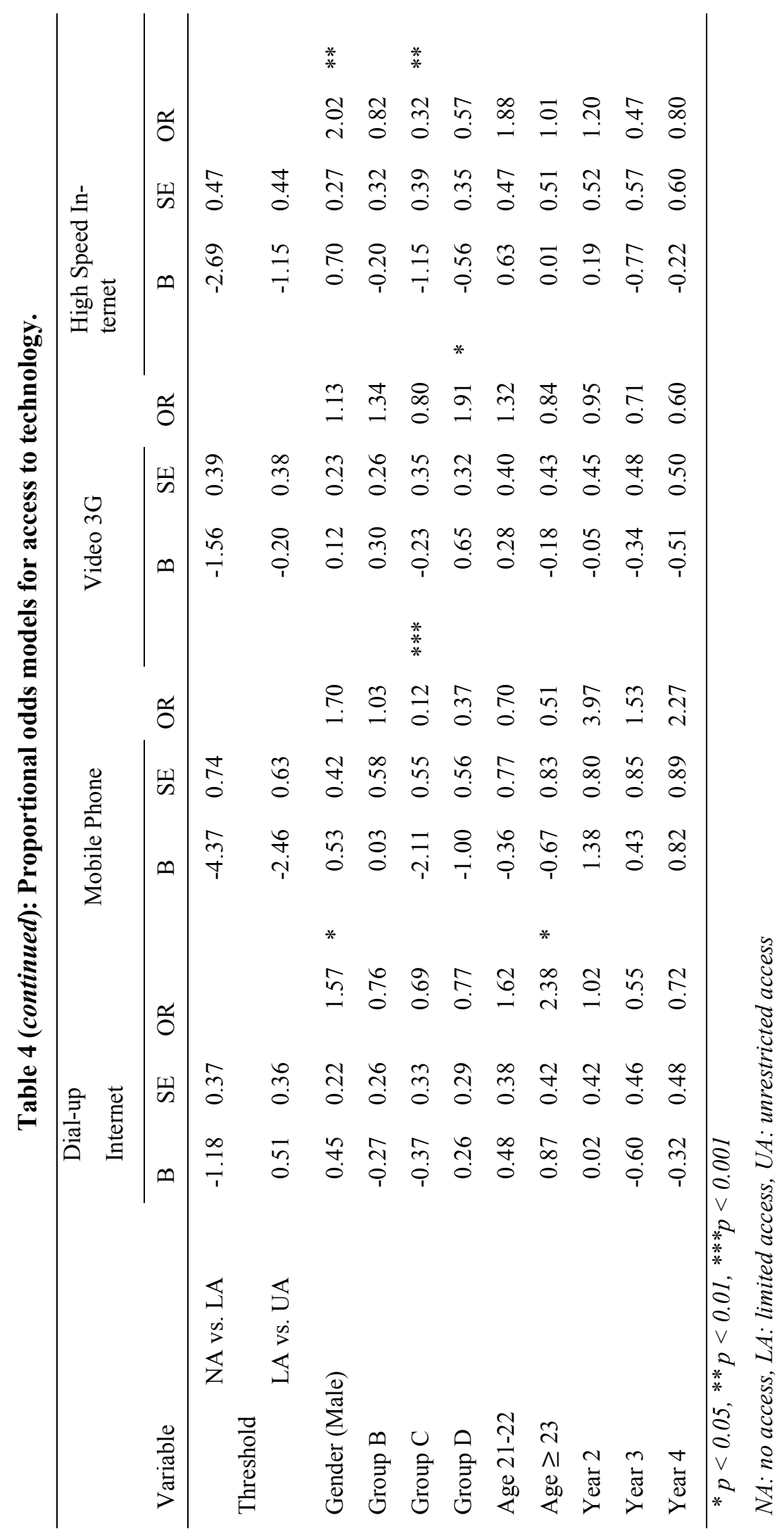




\section{Student Use of Mobile Phone in Learning Environment}

Students were asked about the ways in which they used their mobile phone. Table 5 presents results for those students who selected either 'For learning' or 'For learning and other purposes'. In all groups students reported quite high levels of use of their mobile phones to send text or MSM messages in relation to their studies. However, students from the urban university (Group A and B) were more likely to use their mobile phones to access information or services on the web or send and receive emails.

Table 5: Percentage of students who used mobile phone functions to support learning purpose.

\begin{tabular}{cccc}
\hline Group(A) & Group(B) & Group (C & Group (D) \\
$N=125$ & $N=105$ & $N=45$ & $N=73$
\end{tabular}

Use a mobile phone to text / MSM people

98

95

94
88

86

87
75

40

33
86

32

13

Logistic regression was then used to examine the relationship between student use of various mobile functions in learning environment and student gender and location. Other variables, such as age and year of study were also included in the model to control for possible confounding influence of these variables. The results provided in Table 6 show that there was a significant difference between female students and their male counterparts with respect to sending text or MSM messages. Male students were more likely to use this tool in relation to their studies.

Table 6: Logistic regression models for student use of mobile phone functions to support learning.

\begin{tabular}{|c|c|c|c|c|c|c|c|c|c|}
\hline \multirow[b]{2}{*}{ Variable } & \multicolumn{2}{|c|}{ Text or MSM } & & \multicolumn{2}{|c|}{ Access Info on Web } & & \multicolumn{2}{|c|}{ Send or Receive Email } & \\
\hline & B & SE & & B & SE & & B & SE & \\
\hline (Intercept) & 4.21 & 0.87 & & 2.96 & 0.62 & & 2.74 & 0.66 & \\
\hline $\begin{array}{l}\text { Gender } \\
\text { (Male) }\end{array}$ & 0.88 & 0.43 & $*$ & 0.00 & 0.34 & & 0.16 & 0.37 & \\
\hline Group B & -1.89 & 0.67 & $* *$ & -1.34 & 0.53 & $*$ & -0.99 & 0.51 & \\
\hline Group C & -3.01 & 0.72 & $* * *$ & -3.44 & 0.55 & $* * *$ & -3.55 & 0.54 & $* * *$ \\
\hline Group D & -2.11 & 0.70 & $* *$ & -3.69 & 0.52 & $* * *$ & -4.67 & 0.56 & $* * *$ \\
\hline Age $21-22$ & 0.19 & 0.73 & & 0.26 & 0.57 & & 0.51 & 0.67 & \\
\hline Age $\geq 23$ & 0.14 & 0.81 & & 0.98 & 0.67 & & 0.90 & 0.75 & \\
\hline Year 2 & -0.30 & 0.82 & & -0.42 & 0.60 & & -0.47 & 0.74 & \\
\hline Year 3 & -0.99 & 0.93 & & -0.10 & 0.71 & & -0.70 & 0.82 & \\
\hline Year $\geq 4$ & -1.02 & 0.96 & & -0.84 & 0.76 & & -0.76 & 0.87 & \\
\hline
\end{tabular}

$* p<0.05, * * p<0.01, * * * p<0.001$ 
Table 6 also shows that there was a significant difference in the level of use of mobile phone functions for study purposes between the urban and rural groups. Figure 1 displays estimated probabilities of using the mobile functions in relation to studies for the four groups. The results show that:

- Students in Group B, Group C and Group D were less likely than students in Group A to use a mobile phone to text or MSM other people for study purpose; Group C was the least likely of all.

- Although all three groups B, C and D were less likely than students in Group A to use a mobile to access information or services on the web, students from the rural university reported particularly low levels of use this mobile function for study purpose.

- Similarly, with respect to using a mobile to send or receive emails, students from the rural university reported lower levels of use for study purpose.

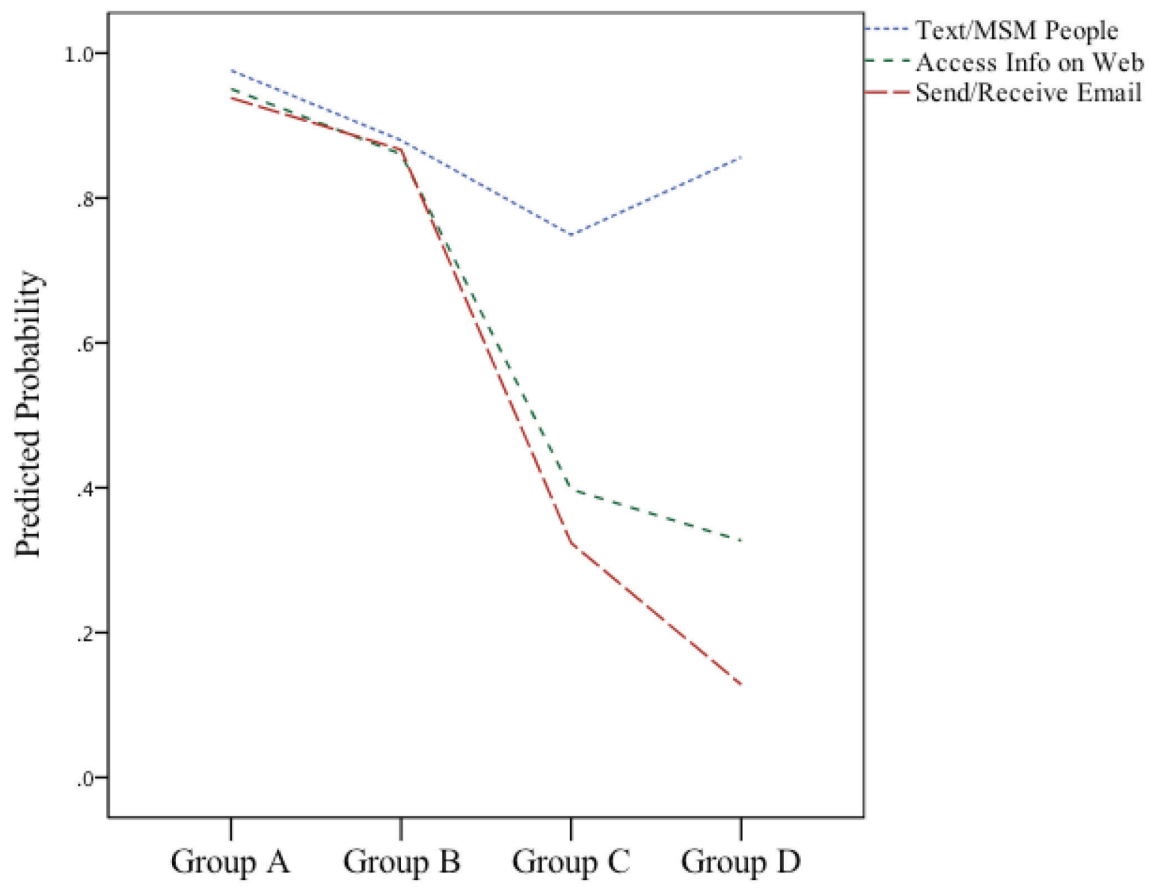

Figure 1: Predicted probability of mobile use to support learning.

\section{Student Perceptions of Usefulness of Mobile Phone to Support Learning}

Students were asked to indicate whether they perceived a mobile phone useful in supporting their learning; four common ways in which a mobile could be utilized in a learning environment were provided to students. Respondents who indicated that they do not know the technology were not included in this analysis. Table 7 presents a summary of student responses regarding their perceptions of the usefulness of mobile phone in supporting their learning. The results are reported as a percentage of those who either disagreed, agreed or were neutral toward each of the statements.

Overall, students in all groups perceived mobile phone as a useful tool in supporting their learning. In particular, receiving grades from teachers and receiving administrative information about 
the course via text message on mobile phone were seen by students as very useful - more than $80 \%$ of respondents in each group would like to use these technologies to support their learning. All groups perceived accessing web-based University information and services as very useful, however, students in Group D were less likely than students in other groups to view this technology useful. Receiving pre-class discussion questions via text message on mobile phone was perceived least favourably of all options provided, with students in Group C providing the lowest scores for usefulness of this technology.

Table 7: Percentage of students who find mobile-based technologies useful to support learning.

\begin{tabular}{|c|c|c|c|c|c|}
\hline & & $\begin{array}{l}\text { Group A } \\
\%(\mathrm{~N})\end{array}$ & $\begin{array}{l}\text { Group B } \\
\%(\mathrm{~N})\end{array}$ & $\begin{array}{c}\text { Group C } \\
\%(\mathrm{~N})\end{array}$ & $\begin{array}{l}\text { Group D } \\
\%(\mathrm{~N})\end{array}$ \\
\hline \multirow{3}{*}{$\begin{array}{l}\text { Use your mobile phone to } \\
\text { access web-based University } \\
\text { services information or ser- } \\
\text { vices }\end{array}$} & Agree & 89 (105) & $86(85)$ & $91(38)$ & $78(52)$ \\
\hline & Neutral & $9(10)$ & $10(10)$ & $7(3)$ & $16(11)$ \\
\hline & Disagree & $2(3)$ & $4(4)$ & $2(1)$ & $6(4)$ \\
\hline \multirow{3}{*}{$\begin{array}{l}\text { Receive grades/marks from } \\
\text { your Lecturer via text mes- } \\
\text { sage on your mobile phone }\end{array}$} & Agree & $92(100)$ & $87(87)$ & $81(35)$ & $90(61)$ \\
\hline & Neutral & $5(6)$ & $7(7)$ & $14(6)$ & $4(3)$ \\
\hline & Disagree & $3(4)$ & $6(6)$ & $5(2)$ & $6(4)$ \\
\hline \multirow{3}{*}{$\begin{array}{l}\text { Receive pre-class discussion } \\
\text { questions from your Lecturer } \\
\text { via text message on your } \\
\text { mobile phone }\end{array}$} & Agree & $79(93)$ & $73(73)$ & $64(31)$ & $88(61)$ \\
\hline & Neutral & $13(15)$ & $18(18)$ & $19(8)$ & $9(6)$ \\
\hline & Disagree & $8(10)$ & $9(9)$ & $7(3)$ & $3(2)$ \\
\hline \multirow{3}{*}{$\begin{array}{l}\text { Receive administrative in- } \\
\text { formation about the course } \\
\text { via text message on your } \\
\text { mobile phone }\end{array}$} & Agree & 87 (104) & 91 (93) & $91(38)$ & $87(60)$ \\
\hline & Neutral & $9(11)$ & $6(6)$ & $9(4)$ & $12(8)$ \\
\hline & Disagree & $4(4)$ & $3(3)$ & $0(0)$ & $1(1)$ \\
\hline
\end{tabular}

\section{Discussion and Conclusion}

The aim of this article was to present initial findings from a larger study examining Libyan engineering students' experiences with technology supported learning. While the research on which this article is based is a case study of only two institutions, the findings presented here extend the small body of work related to e-learning in Libya.

The importance of considering student access to ICTs and student preferences when planning elearning instructional strategies has been well established. A large body of evidence supports the notion of the digital divide, demonstrating that women are disadvantaged when it comes to access to ICT and so are people living in rural areas (Bjørn \& Stein, 2007; Gill et al., 2010; Tortora \& 
Rheault, 2011; UN ICT Task Force, 2002). The findings from this study indicate that the majority of engineering students had unrestricted or at least limited access to most hardware and the Internet connection. Not surprisingly, students in the regional area were less likely than their counterparts in the urban area to have unrestricted access to most technology-based tools and the Internet. The results also indicate that female students were more likely to have limited access to technology-based tools and the Internet than did male students. However, the effect of gender was not significant when looking at students' access to a mobile phone.

Overall, access to a mobile phone was uniform, with an overwhelming majority of students reporting unrestricted access. These findings are comparable with the results of the study conducted in the Gulf region by Sabry et al. (2011). Urban and regional engineering students reported quite high levels of use of their mobile phones to send text or MSM messages to support their learning. Again students from the urban university were more likely to use their mobile phones to access information or services on the web or send and receive emails, compared to their counterparts in the rural area. As would be anticipated, rural university students were less likely to use mobile phone functions that relied on the Internet connection. There was also a significant difference between female students and their male counterparts with respect to sending text or MSM messages for learning; male students were more likely to use this tool.

This high level of usage of mobile phone devices supports the fact that 'today's students believe they are tech-savvy' (Berg, 2005, p.15), and that they are relying on common technologies (computers, mobile phones, and the Internet) for fast communication, and convenient access to information and services (Williams \& Ng'ambi, 2009). For Libya, facing major challenges following the 2011 armed conflict, one of greatest challenges is the reconstruction and redevelopment of the country's education system (Rhema, \& Miliszewska, 2012). It has been suggested in the literature that mobile phones are likely to provide alternative means of communication in Libya where Internet infrastructure is unreliable and limited (Jones et al., 2012).

In this study both, urban and rural engineering students perceived mobile phone as a useful tool of communication for learning purposes. Considering the findings, mobile phones indeed may provide alternative means for student communication. This can help open up accessible educational opportunities, broaden knowledge networks for students, improve availability of quality education materials and help close the digital divide and gender divide in the knowledge economy.

These findings, being limited to a narrow set of questions, are far from exhaustive. Regrettably, the survey did not explore the use of mobile phones in more detail, and most importantly, it omitted the evaluation of other mobile devices. Additional research is also needed to provide a broader evidence base for e-learning implementation in post-conflict Libya. A $\mathrm{PhD}$ research study is currently underway at Victoria University in Australia investigating student experiences with, and perceptions of, technology-based tools among students and educators at two higher education institutions in Libya. It is envisaged that the findings of the research study will serve as a source of information for academics, administrators, and decision-makers involved in planning, design and implementation of e-learning in Libya.

It is important to note that while these findings provide interesting and useful insights, they are based on a case study of only two institutions. Also, students in engineering courses may be more progressive in ICT adoption and have different expectations than other student groups. It would be useful to see if similar findings are obtained for students in other disciplines and other universities. 


\section{References}

Aljazeera News Media. (2011). Libyan News. Retrieved April 13, 2011 from http://www.aljazeera.net/portal

Altameem, T. (2011). Contextual mobile learning system for Saudi Arabian universities. International Journal of Computer Applications, 21(4), 21-26. Retrieved October 15, 2012 from http://www.ijcaonline.org/volume21/number4/pxc3873377.pdf

Andrews, T., Smyth, R., Tynan, B, Berriman, A., Vale, D., \& Caladine, R. (2011). Mobile technologies and rich media: Expanding tertiary education opportunities in developing countries. In A. G. AbdelWahab \& A. A. El-Masry (Eds.), Mobile information communication technologies adoption in developing countries: Effects and implications (pp. 103-116). IGI Global.

Berg, K. (2005). Listening to student voices on technology: Today's tech-savvy students are stuck in textdominated schools. Retrieved October 29, 2012 from http://www.educationevolving.org/pdf/TechSavvy-Students.pdf

Bjørn, F., \& Stein, K. (2007). A rural-urban digital divide? Regional aspects of internet use in Tanzania. Proceedings of the 9th International Conference on Social Implications of Computers in Developing Countries, São Paulo, Brazil, May 2007.

CARICOMICT4D. (2012). Definition of digital divide. Retrieved October 14, 2012 from http://www.caricomict4d.org/ict-for-development-topics-mainmenu-132/digital-divide-mainmenu175/69-definition-of-digital-divide.html

Caudill, J. (2007). The growth of m-Learning and the growth of mobile computing: Parallel developments. The International Review of Research in Open and Distance Learning, 8(2). Retrieved October 21, 2012 from http://www.irrodl.org/index.php/irrodl/article/view/348/873

Chang, C. Y., Sheu, J. P., \& Chan, T. W. (2003). Concept and design of ad hoc and mobile classrooms. Journal of Computer Assisted Learning, 19(3), 336-346.

Cherrayil, N. K. (2010). Mobile subscriptions in Middle East to cross 300m. Gulf News, 2010. Dubai, Al Nisr Publishing. Retrieved October 15, 2012 from http://gulfnews.com/business/telecoms/mobilesubscriptions-in-middle-east-to-cross-300m-1.721749

Gallup. (2011). The Silatech Index: Voices of young Arabs. Retrieved October 17, 2012 from http://sasorigin.onstreammedia.com/origin/gallupinc/media/poll/pdf/Silatech.Report.2011.Apr.pdf

Gill, K., Brooks, K., Mc Dougall, J., Patel, P., \& Kes, A. (2010). Bridging the gender divide: How technology can advance women economically. International Centre for research on Women. Retrieved October 17, 2012, from http://www.icrw.org/files/publications/Bridging-the-Gender-Divide-HowTechnology-can-Advance-Women-Economically.pdf

Gillwald, A., Milek, A., \& Stork, C. (2010). Towards evidence-based ICT policy and regulation: Gender assessment of ICT access and usage in Africa. Research ICT in Africa, 1. Retrieved October 17, 2012 from http://lirneasia.net/wp-content/uploads/2010/09//Gender_Paper_Sept 2010.pdf

Gorski, P. (2001). Understanding the digital divide from a multicultural education framework. Retrieved October 17, 2012 from http://www.edchange.org/multicultural/net/digdiv.html

Hoppe, H. U., Joiner, R., Milrad, M., \& Sharples, M. (2003). Guest editorial: Wireless and mobile technologies in education. Journal of Computer Assisted Learning, 19, 255-259.

International Telecommunication Union. (2012). ICT adoption and prospects in the Arab Region. Retrieved February 20, 2013 from http://www.itu.int/dms pub/itu-d/opb/ind/D-IND-AR-2012-PDF-E.pdf

Iqbal, S., \& Qureshi, I. (2012). M-Learning adoption: A perspective from a developing country. The International Review of Research in Open and Distance Learning, 13(3), 147-164.

Jones, C., Kennedy, S., Kerr, S., Mitchell, J., \& Safayeni, D. (2012). Furthering democracy in Libya with information technology: Opportunities for the international donor community. CIGI Junior Fellows 
Policy Brief, NO. 4. Retrieved October 14, 2012 from

http://www.cigionline.org/sites/default/files/no4 $0 . p d f$

Johnson, L., Adams, S., \& Cummins, M. (2012). The NMC horizon report: 2012 higher education edition. Austin, Texas: The New Media Consortium.

Johnson, L., Levine, A., \& Smith, R. (2008). The 2008 horizon report: Australia-New Zealand Edition. Austin, Texas: The New Media Consortium.

Kennedy, G., Krause, K., Gray, K., Judd, T., Bennett, S., Maton, K. Dalgarno,B., \& Bishop, A. (2006). Questioning the net generation: A collaborative project in Australian higher education. In L. Markauskaite, P. Goodyear, \& P. Reimann (Eds), Who's learning? Whose technology? Proceedings of the 23rd Annual Conference of the Australiasian Society for Computers in Learning in Tertiary Education, 413-417. Sydney: Sydney University Press.

Kim, C., Lee, J., Merrill, M. D., Spector, J. M., \& van Merriënboer, J. J. G. (2008). Foundations for the future. In J. M. Spector, M. D. Merrill, J. J. G. van Merriënboer \& M. P. Driscoll (Eds.), Handbook of research on educational communications and technology (3rd ed.), pp. 807-815, New York: Erlbaum/Routledge.

Kok, A. (2011). In defence of mobile technologies: Exploring the socio-technological dimensions of mlearning. University of Oxford, UK.

Libyan Ministry of Communication and Informatics. (2012). E-Libya initiative. Retrieved October 14, 2012 from http://www.cim.gov.ly/page53.html

Liff, S., \& Shepherd, A. (2004). An evolving gender digital divide? The University of Oxford for the Oxford Internet Institute. Retrieved October 14, 2012 from http://educ.ubc.ca/faculty/bryson/565/genderdigdiv.pdf

Liu, T. C., Wang, H. Y., Liang, J. K., Chan, T. W., Ko, H. W.,\& Yang, J. C. (2003).Wireless and mobile technologies to enhance teaching and learning. Journal of Computer Assisted Learning, 19(3), 371382.

Muttoo, S. (2011). Mobile changes in the Arab world. Retrieved October 14, 2012 from http://www.strategicforesight.com/mobile changes.htm

Nair, M., Han, G., Lee, H., Goon, P., \& Muda, R. (2010). Determinants of the digital divide in rural communities of a developing country: The case of Malaysia. Development and Society, 39(1), 139-162. Retrieved October 29, 2012, from http://isdpr.org/isdpr/publication/journal/39-1/06.pdf

Nash, S. (2011). Blended mobile learning in developing nations and environments with variable access. In A. G. Abdel-Wahab \& A. A. El-Masry (Eds.) Mobile information communication technologies adoption in developing countries: Effects and implications (pp. 91-102). IGI Global.

Orr, G. (2010). Review of literature in mobile learning: Affordances and constraints. Proceedings of the 6th IEEE International Conference on Wireless, Mobile, and Ubiquitous Technologies in Education, Taiwan, 107-111.

Puumalainen, K., Frank, L., Sundqvist, S., \& Tappura, A. (2011). The critical mass of wireless communications: Differences between developing and developed economies. In A. G. Abdel-Wahab \& A. A. ElMasry (Eds.) Mobile information communication technologies adoption in developing countries: Effects and implications (pp. 1-17). IGI Global.

Rhema, A., \& Miliszewska, I. (2012). The potential of e-learning in assisting post-crisis countries in rebuilding their higher education systems: The case of Libya. Issues in Informing Science and Information Technology, 9, 149-160. Retrieved from http://iisit.org/Vol9/IISITv9p149-160Rhema033.pdf

Sabry, K., Al-Nakeeb, A., \& Alrawi, K. (2011). Mobile technology and the gulf society: Perceptions and attitude. In A. G. Abdel-Wahab \& A. A. El-Masry (Eds.) Mobile information communication technologies adoption in developing countries: Effects and implications (pp. 195-204). IGI Global.

Suki, N., \& Suki, N. (2007). Mobile phone usage for m-learning: Comparing heavy and light mobile phone users. Campus-Wide Information Systems, 24(5), 355-365. 
Sun, Y. T. (2008). The practice and research of m-learning and mobile service. Journal of Distance Education in China, 8, 68-70.

Sun, Y. T., \& Chen, X. (2007). Research on the building of mobile campus in the open universities. Journal of Educational Informatization in China, 10, 7-9.

Tortora, B., \& Rheault, M. (2011). Mobile phone access varies widely in Sub-Saharan Africa. Retrieved February 21, 2013 from http://www.gallup.com/poll/149519/mobile-phone-access-varies-widely-subsaharan-africa.aspx\#1

Traxler, J. (2007). Defining, discussing and evaluating mobile learning: The moving finger writes and having writ. The International review of Research in Open and Distance Learning, 8(2). Retrieved October 24, 2012 from http://www.irrodl.org/index.php/irrodl/article/view/346/875\%2Bdiscussing\%26amp\%3Bsa\%3DX

UN ICT Task Force. (2002). Information and communication technologies in Africa - A status report. Third Task Force Meeting United Nations Headquarters, 30 September - 1October 2002.

UNESCO. (2012). Turning on mobile learning in Africa and the Middle East. Retrieved October 15, 2012 from http://unesdoc.unesco.org/images/0021/002163/216359e.pdf

United Nations. (2005). Gender equality and empowerment of women through ICT. Retrieved October 20, 2012 from http://www.un.org/womenwatch/daw/public/w2000-09.05-ict-e.pdf

Uys, P. M., Brann, J., Klapdor T., \& Smith, M. (2012). Mobile learning in eHealth: Increasing learning options by supporting the mobility of learners in developing contexts. In I. Mathias\& A. Monteiro (Eds), Gold e-Book ehealth and tele-education. EdUERJ:University Hospital Pedro Ernesto of State University of Rio de Janeiro.

Venables, W. N., \& Ripley, B. D. (2002). Modern applied statistics with S-Plus (4th ed). New York: Springer-Verlag.

Williams, C., \& Ng'ambi, D. (2009). Case study 5: Mobile learning. Report of the Opening Scholarship Project funded by the Shuttleworth Foundation. Retrieved October 15, 2012 from http://www.cet.uct.ac.za/files/file/OS\%20CaseStudy5\%20\%20\%20Final\%20typeset.pdf

Yang, Y., \& Wang, Q. (2011). Mobile learning in China. In A. G. Abdel-Wahab \& A. A. El-Masry (Eds.) Mobile information communication technologies adoption in developing countries: Effects and implications (pp. 79-90). IGI Global.

Zuckerman, E. (2009). Web 2.0 tools for development: simple tools for smart people. In H. Ashley, N. Kenton, \& A. Milligan (Eds.), Change at hand: Web 2.0 for development. Participatory Learning and Action no. 59 (June): 87-94. Retrieved October 29, 2012 from http://pubs.iied.org/pdfs/G02845.pdf 


\section{Appendix A}

For each technology, separate models were developed. The basic model fitted

$$
\operatorname{logit} P(Y \leq k \mid x)=\zeta_{k}-\eta
$$

where the logit transformation

$$
\operatorname{logit}(p)=\log \left(\frac{p}{1-p}\right)
$$

ensures the estimated probabilities lie between 0 and $1 ; Y$ is the response variable with $K$ levels, $1,2, \ldots, \mathrm{K} ; \boldsymbol{x}$ is the vector of explanatory variables; $\zeta_{k}$ (pronounced 'zeta'), with

$\zeta_{0}=-\infty<\zeta_{1}<\ldots<\zeta_{K}=\infty$, are estimated thresholds, discussed below; and $\eta$ (pronounced 'eta') is the estimated linear predictor of the explanatory variables, (Venables and Ripley, 2002, pp. 204-205).

One way to think about the model is to imagine that there is an unobserved (or latent) response variable for each student. If this response variable for a particular student is less than $\zeta_{1}$, then the students selects the first response category; if the response variable is between $\zeta_{1}$ and $\zeta_{2}$, then the student selects the second response category; and so on. If the response variable is above $\zeta_{K}$ then the student selects the highest response category. Technically, the distribution of the latent variable follows a standard logistic distribution, which is almost the same as a normal distribution but with a standard deviation of 1.6.

The models were summarised by diagrams presented in Appendix B.

\section{Appendix B}

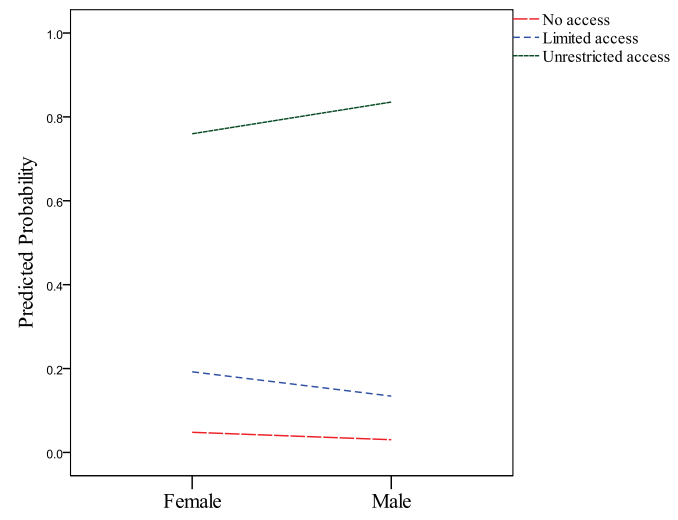

(a) desktop computer

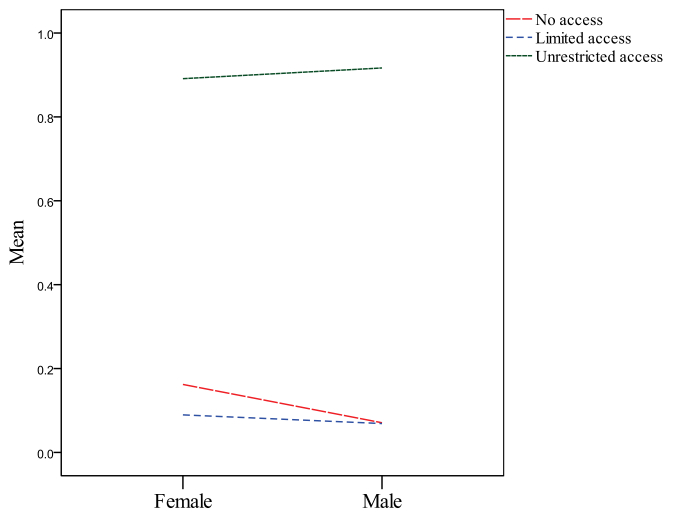

(b) portable computer 


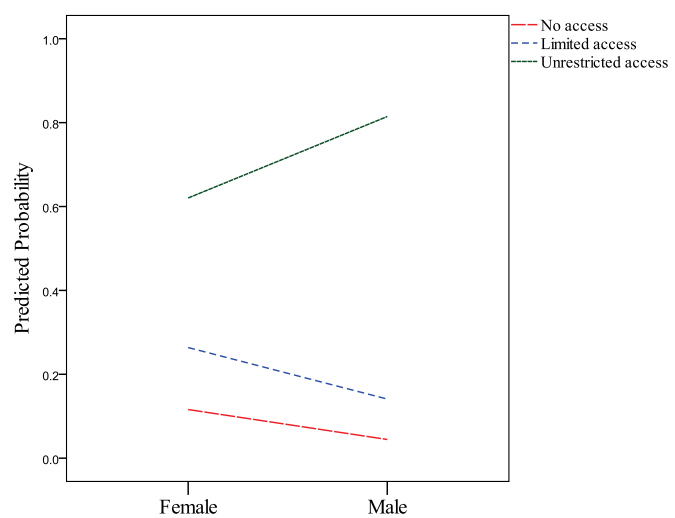

(c) memory stick

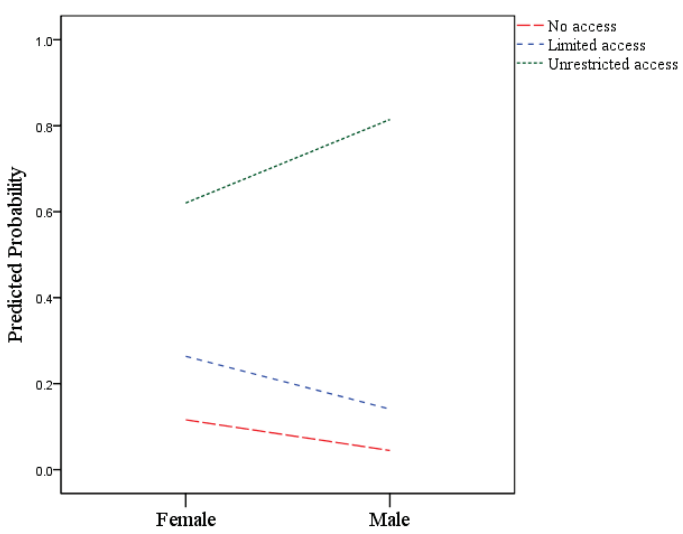

(e) dial-up Internet

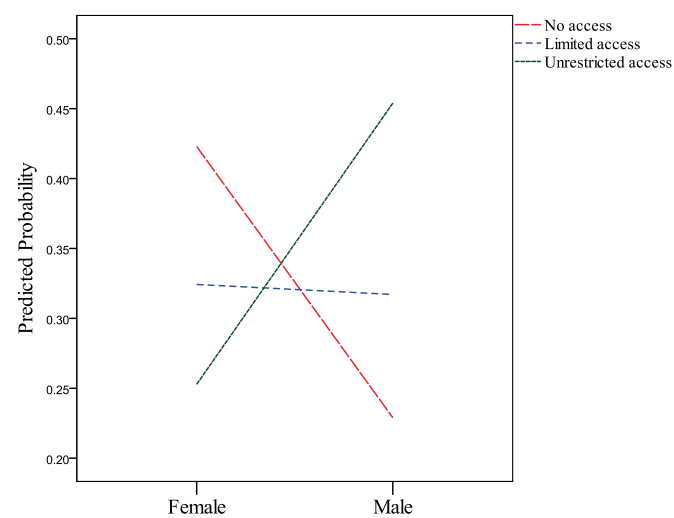

(d) web camera

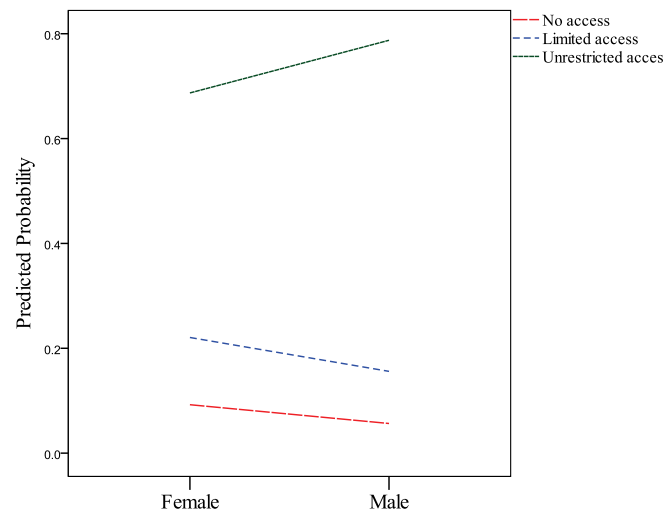

(f) high-speed Internet

Figure A1: Predicted probability for level of access by gender to (a) desktop computer, (b) portable computer, (c) memory stick, (d) web camera, (e) dial-up Internet, and (f) high-speed Internet.
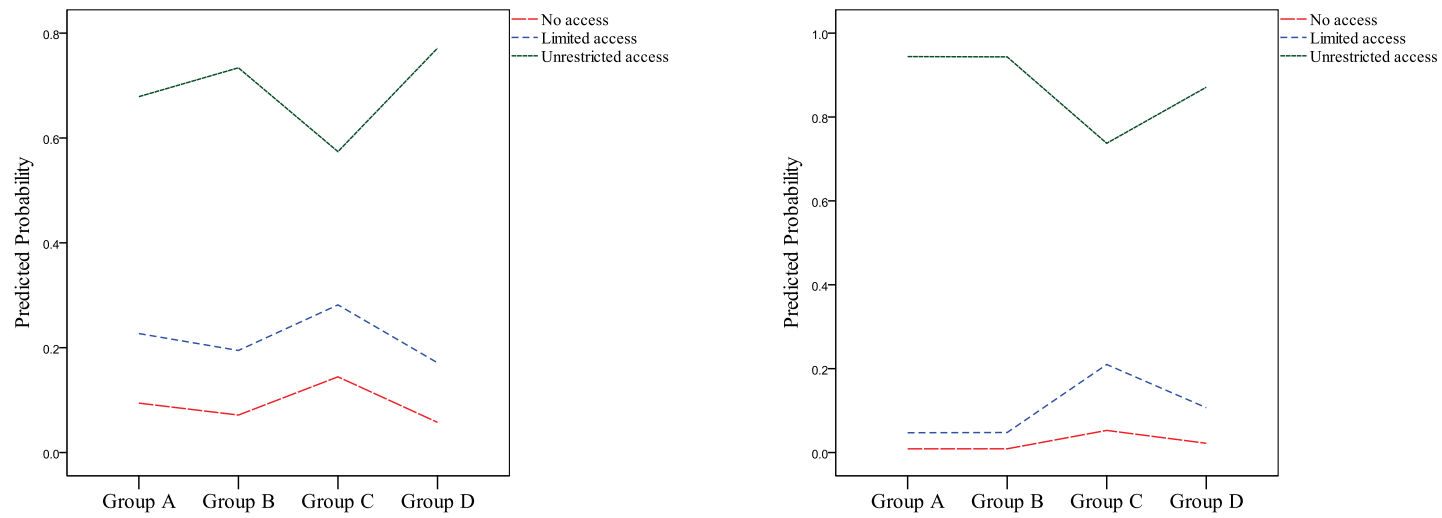
(a) memory stick

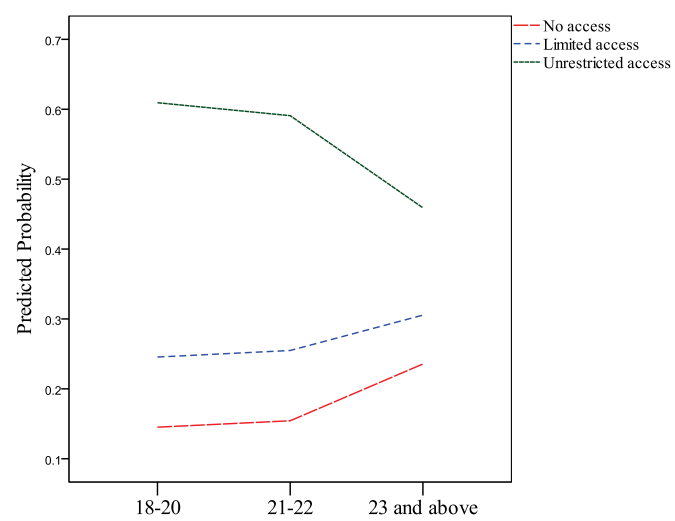

(c) video $3 \mathrm{G}$ (b) mobile phone

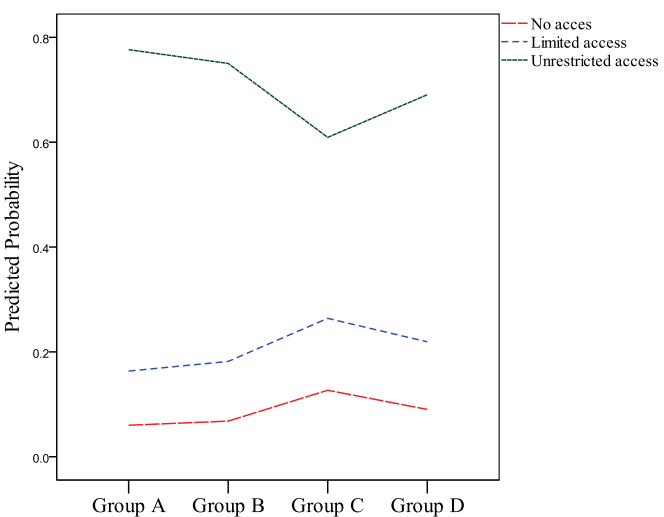

(d) high-speed Internet

Figure A2: Predicted probability for level of access by group to (a) desktop computer, (b) portable computer, (c) memory stick, (d) web camera, (e) dial-up Internet, and (f) high-speed Internet.

\section{Appendix C}

(Only relevant sections from

a PhD study survey are presented here)
VICTORIA UNIVERSITY

Section 1: Demographics

Gender:

$\square$ Male $\square$ Female

Age:

ㄱ $18-20$

$\square 21-22$

$\square 23$ and older

Year of studies:

$\square 1$

$\square 2$

$\square 3$

$\square 4$ and higher

Section 2: Access to Technology

Please indicate your level of access to different types of technologies (outside University). Please tick only one answer.

\begin{tabular}{|c|c|c|c|}
\hline Types of Technology & No Access & Limited Access & $\begin{array}{l}\text { No Problem } \\
\text { with Access }\end{array}$ \\
\hline Desktop computer & 口 & $\square$ & $\square$ \\
\hline $\begin{array}{l}\text { Portable computer (i.e. laptop or note- } \\
\text { book) }\end{array}$ & $\square$ & $\square$ & $\square$ \\
\hline Dedicated digital camera & $\square$ & $\square$ & $\square$ \\
\hline Mobile phone & $\square$ & $\square$ & $\square$ \\
\hline Video (3G) capable phones & $\square$ & $\square$ & $\square$ \\
\hline $\begin{array}{l}\text { Memory stick (e.g. flash drive, USB } \\
\text { stick) }\end{array}$ & $\square$ & $\square$ & $\square$ \\
\hline Web cam & $\square$ & $\square$ & $\square$ \\
\hline
\end{tabular}




\begin{tabular}{|l|c|c|c|}
\hline Dial-up internet access & $\square$ & $\square$ & $\square$ \\
\hline $\begin{array}{l}\text { Broadband internet access (ADSL or } \\
\text { cable) }\end{array}$ & $\square$ & $\square$ & $\square$ \\
\hline Wireless internet access & $\square$ & $\square$ & $\square$ \\
\hline
\end{tabular}

\section{Section 3: Use of Technology}

Below is a list of different ways in which ICT can be used. Please indicate: (1) If you have used technology for learning purposes and /or other purposes (e.g. entertainment); tick all that apply, and (2) If you are not sure about a particular technology, please tick "Don't know".

\begin{tabular}{|l|c|c|c|}
\hline \multicolumn{1}{|c|}{ Types of Technology } & For learning & For other purposes & Don't know \\
\hline Use a mobile phone to text / MSM people & $\square$ & $\square$ & $\square$ \\
\hline $\begin{array}{l}\text { Use a mobile phone to access information/ } \\
\text { services on the web }\end{array}$ & $\square$ & $\square$ & $\square$ \\
\hline Use a mobile phone to send or receive email & $\square$ & $\square$ & $\square$ \\
\hline
\end{tabular}

\section{Section 4: Perceived Usefulness of Technology in Learning}

Below is a list of different ways in which technology may be used to help you with your studies at University.

Please indicate your agreement with how useful each of the following technologies is in your study; circle the number that best represents your opinion - 1 indicates "Strongly disagree" and 5 indicates "Strongly agree". If you are not sure about a particular technology, please tick "Don't know".

\begin{tabular}{|c|c|c|c|c|c|c|}
\hline $\begin{array}{l}\text { In your studies, how useful do you think it would } \\
\text { be to: }\end{array}$ & $\begin{array}{l}\text { Strongly } \\
\text { disagree }\end{array}$ & Disagree & Neutral & Agree & $\begin{array}{l}\text { Strongly } \\
\text { agree }\end{array}$ & $\begin{array}{l}\text { Don't } \\
\text { Know }\end{array}$ \\
\hline $\begin{array}{l}\text { Use your mobile phone to access web-based Universi- } \\
\text { ty services information or services (e.g. enrolment, } \\
\text { sign up for tutes, pay fees)? }\end{array}$ & 1 & 2 & 3 & 4 & 5 & $\square$ \\
\hline $\begin{array}{l}\text { Receive grades/marks from your Lecturer via text } \\
\text { message on your mobile phone? }\end{array}$ & 1 & 2 & 3 & 4 & 5 & $\square$ \\
\hline $\begin{array}{l}\text { Receive pre-class discussion questions from your } \\
\text { Lecturer via text message on your mobile phone? }\end{array}$ & 1 & 2 & 3 & 4 & 5 & $\square$ \\
\hline $\begin{array}{l}\text { Receive administrative information about the course } \\
\text { via text message on your mobile phone (e.g. timetable } \\
\text { or assessment changes, information on new learning } \\
\text { resources? }\end{array}$ & 1 & 2 & 3 & 4 & 5 & $\square$ \\
\hline
\end{tabular}




\section{Biographies}

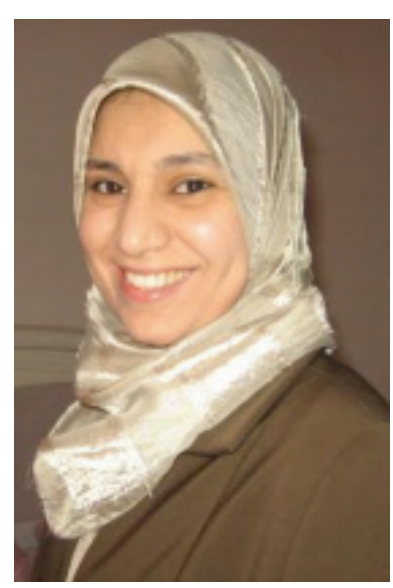

Mrs Amal Rhema is a PhD candidate in the School of Engineering and Science at Victoria University in Melbourne, Australia where she is currently undertaking a research project entitled "An analysis of experiences and perceptions of technology-based learning in higher education institutions in Libya: informing the advancement of e-learning through case studies".

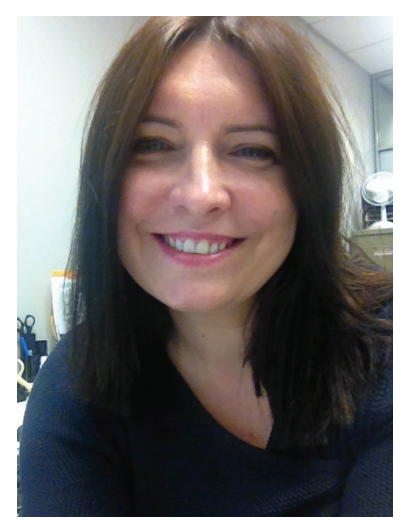

Dr Ewa Sztendur is a Senior Statistical Consultant with the Office of the Pro Vice-Chancellor (Research \& Research Training) and Research Fellow in the Office of the Pro Vice-Chancellor (Academic \& Students) at Victoria University, Australia. She has a PhD in statistics in the area of experimental design. She has consulted and lectured in statistics at the University of Melbourne, Monash University and Victoria University. She has been involved in numerous research and evaluation projects in the field of education in a capacity of a statistical expert. 